\title{
Mekanisme Jual Putus Sebelum dan Sesudah Berlakunya Undang-Undang Tentang Hak Cipta dalam Perspektif Pembangunan Ekonomi Nasional di Era Globalisasi
}

\author{
Sudjana \\ Fakultas Hukum, Universitas Padjajaran, Bandung \\ Email : sdjana@yahoo.com
}

Info Artikel:

| Diterima: 12 Februari 2019

| Disetujui: 28 Juni 2019

| Dipublikasikan: 02 Juli 2019

\begin{abstract}
This study aims to determine the enactment of Law Number 28 of 2014 concerning Law No. 19 of 2002 relating to the "Sold Flat" mechanism before and after the enactment of Law Number 28 of 2014 in the Perspective of National Economic Development in the Globalization Era. The research method used is the normative and juridical comparative juridical approach, the specification of analytical descriptive research, the research phase is carried out through the study of literature to examine primary legal materials, secondary legal materials, and tertiary legal materials. Data collection techniques are carried out through document study, which is done by reviewing documents about positive law. Furthermore, data analysis methods are carried out through qualitative normative. The results of the study show that: (1). the secondary linking point (determinant) of the enactment of Law Number 28 of 2014 concerning Law Number 19 of 2002 based on "Lexus exterior derogat priori" (the new law disregards the old law); (2). The "sold flat" mechanism can be a means of National Economic Development in the Globalization Era if it is supported by consistent law enforcement, adequate facilities, community legal awareness and a conducive legal culture. Keywords: Sold flat, Copyright Law, National Economic Development, Globalization Era.
\end{abstract}

\begin{abstract}
Abstrak
Kajian ini bertujuan untuk menentukan keberlakuan Undang-Undang Nomor 28 Tahun 2014 terhadap UU No 19 Tahun 2002 berkaitan dengan mekanisme "Jual Putus (Sold Flat)" sebelum dan sesudah berlakunya Undang-Undang Nomor 28 Tahun 2014 dalam Perspektif Pembangunan Ekonomi Nasional di Era Globalisasi. Metode Penelitian yang digunakan adalah Metode pendekatan yuridis normatif dan yuridis komparatif, Spesifikasi penelitian deskriptif analitis, Tahap penelitian dilakukan melalui studi kepustakaan untuk meneliti bahan hukum primer, bahan hukum sekunder, dan bahan hukum tersier. Teknik pengumpulan data dilakukan melalui studi dokumen, yang dilakukan dengan mengkaji dokumendokumen tentang hukum positif. Selanjutnya Metode analisis data dilakukan melalui normatif kualitatif. Hasil kajian menunjukan bahwa: (1). titik pertautan sekunder (penentu) keberlakuan Undang-Undang Nomor 28 Tahun 2014 terhadap Undang-Undang Nomor 19 Tahun 2002 berdasarkan "lexposterior derogat priori" (hukum yang baru mengenyampingkan hukum yang lama); (2). Mekanisme "jual putus (sold flat)" dapat menjadi sarana Pembangunan Ekonomi Nasional di Era Globalisasi apabila didukung dengan penegak hukum yang konsisten, sarana fasilitas yang memadai, kesadaran hukum masyarakat dan budaya hukum yang kondusif.
\end{abstract}

Kata Kunci : Jual Putus, UU Hak Cipta, Pembangunan Ekonomi nasional, Era Globalisasi. 


\section{A. PENDAHULUAN}

Globalisasi merupakan tantangan dan peluang bagi Indonesia karena harus menghadapi persaingan di tingkat dunia, tetapi hal tersebut juga merupakan kesempatan untuk berkiprah dalam pergaulan internasional dengan melakukan peningkatan di segala bidang terutama ekonomi karena berkaitan dengan upaya mensejahterakan seluruh rakyat Indonesia sebagaimana amanat Pembukaan UUD 1945 Amandemen 4 tentang Tujuan nasional, yaitu "memajukan kesejahteraan umum." Untuk mencapai tujuan tersebut, perlu dilakukan kebijakan dalam upaya meningkatan ekonomi nasional melalui pengaturan yang kondusif dengan tetap memperhatikan kepentingan Indonesia di tingkat internasional, karena itu harmonisasi kepentingan nasional dan internasional merupakan 2 (dua) hal yang tidak dapat dipisahkan.

Secara nasional dari sisi hukum, salah satu yang perlu ditingkatkan adalah perlindungan yang lebih memadai terhadap pencipta melalui pengaturan Hak Cipta, karena kreasi yang dihasikan melalui penggunaan intelektual tersebut memiliki nilai ekonomi tinggi yang secara mikro berakibat pada peningkatan ekonomi dari pencipta itu sendiri dan secara makro merupakan indikator peningkatan ekonomi nasional.

Hak Cipta merupakan salah satu bagian dari kekayaan intelektual yang memiliki ruang lingkup objek dilindungi paling luas, karena mencakup ilmu pengetahuan, seni dan sastra (art and literary) yang di dalamnya mencakup pula program komputer. ${ }^{1} \quad$ Pengaturan Hak Cipta sejak merdeka dimulai tahun 1982 (12 April 1982) dengan dikeluarkannya Undang-Undang (UU) Nomor (No) 6 Tahun 1982 yang menggantikan UU pada zaman Hindia Helanda yaitu Auteurswet 1912 Staatsblad Nomor 600 Tahun 1912. Namun, pemerintah

\footnotetext{
${ }^{1}$ Penjelasan Umum UU No 28 Tahun 2014 Tentang Hak Cipta (UUHC).
}

menganggap perlu adanya perubahan untuk menyempurnakan UU No. 6 Tahun 1982, sehingga dikeluarkan UU No. 7 tahun 1987 dengan memperluas masa berlakunya perlindungan karya cipta diperpanjang menjadi 50 tahun setelah meninggalnya pencipta. Karya-karya seperti rekaman dan video dikategorikan sebagai karya-karya yang dilindungi. Selain itu, yang dianggap kelemahan dari UU No. 6 Tahun 1982 adalah kerena menganut delik aduan, sehingga melalui UU No. 7 Tahun 1987, diubah menjadi delik biasa. Selanjutnya, UU No. 6 Tahun 1982 jo UU No. 7 Tahun 1987 diubah dengan UU No. 12 Tahun 1997 Tentang Perubahan atas UU No. 6 Tahun 1982 Tentang Hak Cipta yang telah diubah UU No. 7 Tahun 1987. Perubahan UU ini dilatarbelakangi keikutsertaan Indonesia dalam Persetujuan tentang Aspek-Aspek Dagang Hak Atas Kekayaan Intelektual (Agreement on Trade Related Aspect of Intellectual Property Rights, Including Trade Counterfeit Goods/ TRIPs) yang merupakan bagian dari Persetujuan Pembentukan Organisasi Perdagangan Dunia (Agreement Establishing the World Trade Organization) dengan meratifikasi melalui melalui Nomor 7 Tahun 1994 dan meratifikasi ${ }^{2}$ Berne Convention for the Protection of Arstistic and Literary Works (Konvensi Berne tentang Perlindungan Karya Seni dan Sastra) melalui Keputusan Presiden Nomor 18 Tahun 1997 dan World Intellectual Property Organization Copyrights Treaty (Perjanjian Hak Cipta WIPO) dengan Keputusan Presiden Nomor 19 Tahun 1997. ${ }^{3}$ Namun, meskipun UU No. 12 Tahun 1997 telah memuat beberapa

\footnotetext{
${ }^{2}$ Pasal 2 Konvensi Wina 1969: ratifikasi didefinisikan sebagai tindakan internasional dari suatu Negara menyatakan kesediaannya atau melahirkan persetujuan untuk diikat oleh suatu perjanjian internasional.

${ }^{3}$ Pada tahun 2004 Indonesia juga telah meratifikasi World Intellectual Property Organization Performances and Phonograms Treaty (Perjanjian Karya-Karya Pertunjukan dan Karya-Karya Fonogram WIPO) yang selanjutnya disebut WPPT, melalui Keputusan Presiden Nomor 74 Tahun 2004.
} 
penyesuaian pasal yang sesuai dengan Perjanjian TRIPs, masih terdapat beberapa hal yang perlu disempurnakan untuk memberi perlindungan bagi karya-karya intelektual di bidang hak cipta, termasuk upaya untuk memajukan perkembangan karya intelektual yang berasal dari keanekaragaman seni dan budaya bangsa Indonesia, sehingga perlu untuk mengganti UUHC tersebut dengan UU No. 19 Tahun 2002 Tentang Hak Cipta. Selanjutnya, kekayaan seni dan budaya, serta pengembangan kemampuan intelektual masyarakat Indonesia memerlukan perlindungan hukum yang memadai agar terdapat iklim persaingan usaha yang sehat yang diperlukan dalam melaksanakan pembangunan nasional, maka dibentuklah UU yang baru, yakni UU No. 28 Tahun 2014 Tentang Hak Cipta (selanjutnya disebut UUHC) agar sesuai dengan perkembangan hukum dan kebutuhan masyarakat, ${ }^{4}$ sebagaimana yang tercantum dalam bagian menimbang UU tersebut, yaitu:

a. bahwa hak cipta merupakan kekayaan intelektual di bidang ilmu pengetahuan, seni, dan sastra yang mempunyai peranan strategis dalam mendukung pembangunan bangsa dan memajukan kesejahteraan umum sebagaimana diamanatkan oleh UUD Negara Republik Indonesia Tahun 1945;

b. bahwa perkembangan ilmu pengetahuan, teknologi, seni, dan sastra, sudah demikian pesat sehingga memerlukan peningkatan pelindungan dan jaminan kepastian hukum bagi pencipta, pemegang Hak Cipta, dan pemilik Hak Terkait;

c. bahwa Indonesia telah menjadi anggota berbagai perjanjian internasional di bidang hak cipta dan hak terkait sehingga diperlukan

\footnotetext{
4 http://www.landasanteori.com/2015/09/hak-ciptasejarah-perkembangan.html.[diakses 5/7/2018]
}

implementasi lebih lanjut dalam sistem hukum nasional agar para pencipta dan kreator nasional mampu berkompetisi secara internasional;

d. bahwa UU No.19 Tahun 2002 Tentang Hak Cipta sudah tidak sesuai dengan perkembangan hukum dan

kebutuhan masyarakat sehingga perlu diganti dengan UU yang baru.

Perkembangan ekonomi kreatif yang menjadi salah satu andalan Indonesia dan berbagai negara dan berkembang pesatnya teknologi informasi dan komunikasi mengharuskan adanya pembaruan UU Hak Cipta, mengingat Hak Cipta menjadi basis terpenting dari ekonomi kreatif nasional. Dengan UU Hak Cipta yang memenuhi unsur pelindungan dan pengembangan ekonomi kreatif ini maka diharapkan kontribusi sektor Hak Cipta dan Hak Terkait bagi perekonomian negara dapat lebih optimal. ${ }^{5}$

Langkah DPR dan Pemerintah mengganti UU No. 19 Tahun 2002 Tentang Hak Cipta dengan UU No. 28 Tahun 2014 adalah upaya sungguh-sungguh dari negara untuk melindungi hak ekonomi dan hak moral Pencipta dan pemilik Hak Terkait sebagai unsur penting dalam pembangunan kreativitas nasional. Teringkarinya hak ekonomi dan hak moral dapat mengikis motivasi para Pencipta dan pemilik Hak Terkait untuk berkreasi. Hilangnya motivasi seperti ini akan berdampak luas pada runtuhnya kreativitas makro bangsa Indonesia. Bercermin kepada Negara-negara maju tampak bahwa pelindungan yang memadai terhadap Hak Cipta telah berhasil membawa pertumbuhan ekonomi kreatif secara signifikan dan memberikan kontribusi nyata bagi perekonomian dan kesejahteraan rakyat. ${ }^{6}$

Salah satu issue yang diangkat berkaitan dengan disahkannya UU No. 28 Tahun 2014 adalah memberikan Pelindungan yang lebih baik terhadap hak ekonomi para

\footnotetext{
${ }^{5}$ Penjelasan Umum UUHC.

${ }^{6}$ Ibid.
} 
Pencipta dan/atau Pemilik Hak Terkait, termasuk membatasi pengalihan hak ekonomi dalam bentuk jual putus (sold flat) yang tidak diatur dalam UU Hak Cipta sebelumnya. Namun, yang menjadi permasalahan antara lain mengenai keberlakukan UU No. 28 Tahun 2014 terhadap UU No. 19 Tahun 2002 berkaitan dengan Hukum Antar Waktu. Serta bagaimana ketentuan jual lepas (sold flat) dalam UU No 28 Tahun 2014 agar dapat menjadi salah satu sarana pembangunan ekonomi nasional di era globalisasi. Oleh karena itu, peneliti mencoba mengurai persoalan terkait dengan jual putus dalam perspektif pemabangunan ekonomi nasional.

\section{B. METODE PENELITIAN}

Metode Penelitian yang digunakan adalah Metode pendekatan yuridis normatif yaitu pendekatan yang dilakukan terhadap norma, asas hukum, Spesifikasi penelitian deskriptif analitis, dalam arti menjelaskan permasalahan kemudian menganalisis berdasarkan konstruksi hukum dan penafsiran hukum. Tahap penelitian dilakukan melalui studi kepustakaan untuk meneliti bahan hukum primer, bahan hukum sekunder, dan bahan hukum tersier. Teknik pengumpulan data dilakukan melalui studi dokumen, yaitu dengan mengkaji dokumendokumen tentang hukum positif. Selanjutnya Metode analisis data dilakukan melalui normatif kualitatif, dalam arti analisis terhadap kualifikasi norma atau kaidah hukum tidak menggunakan perhitungan atau rumus statistika.

\section{PEMBAHASAN}

\section{Keberlakukan UU No. 28 Tahun 2014 terhadap UU No. 19 Tahun 2002 berkaitan dengan Hukum Antar Waktu}

Dasar keberlakuan sebuah UU harus memperhatikan 3 (tiga) syarat, yaitu syarat filosofis, yuridis, dan sosiologis. Secara filosofis, sebuah UU harus sesuai dengan citacita hukum (rechtsidee) sebagai nilai positif yang tertinggi dan memcerminkan tujuan hukum yang luhur yaitu ketertiban, keadilan dan kemanfaatan. Menurut Kelsen, syarat yuridis, yaitu hukum (UU) tersebut penentuannya didasarkan pada kaedah yang lebih tinggi tingkatannya (khirarkhi). Selanjutnya, Menurut Kelsen, suatu UU atau peraturan berlakunya harus didasarkan pada norma dasar (grundnorm) yang lebih tinggi tingkatannya dan mendasar. ${ }^{7}$ Hans Nawiasky menyebutnya sebagai "staatsfundamentalnorm". ${ }^{8}$ John Alder berpendapat bahwa suatu UU atau peraturan mempunyai kekuatan yuridis harus berdasarkan"basic principle" dan "general political and moral value". ${ }^{9} \mathrm{~W}$. Zevenbergen, mengemukakan bahwa kaidah hukum mempunyai kekuatan yuridis, apabila kaidah tersebut dibentuk menurut cara yang telah ditetapkan. ${ }^{10}$ Sedangkan menurut J.H.A. Logemann, Kaidah hukum mengikat secara yuridis, apabila menunjukkan hubungan keharusan antara suatu kondisi dengan akibatnya. $^{11}$

Apabila pengaturan "sold flat" dikaji dari syarat filosofis, maka norma tersebut sudah mencerminkan rasa keadilan memberikan perlindungan lebih baik bagi pencipta sehingga diharapkan pencipta termotivasi untuk menciptakan kreasinya lebih banyak dan pada saat hak ekonominya dialihkan setelah berakhir 25 tahun akan kembali pada penciptanya. Hak ekonomi merupakan hak eksklusif Pencipta atau Pemegang Hak Cipta untuk mendapatkan manfaat ekonomi atas Ciptaan. ${ }^{12}$ Manfaat ekonomi berkaitan dengan "sold flat" adalah

\footnotetext{
${ }^{7}$ Maria Farida Indrati Soeprapto. 1988. Ilmu Perundang-undangan, Dasar-dasar dan Pembentukannya. Kanisius, Yogyakarta, hlm. 28-30.

${ }^{8}$ Jimly Asshiddiqie, Hukum Acara Pengujian UndangUndang, Sekretariat jenderal dan Kepaniteraan Mahkamah Konstitusi RI, Jakarta Pusat, 2005, hlm 15.

${ }^{9}$ Ibid. hlm 13-15.

${ }^{10}$ Purnadi Purbacaraka dan Soerjono Soekanto, Perihal Kaidah Hukum, Cet. Keempat, Alumni, Bandung, 1986, hlm. 108-110.

11 Ibid.

${ }^{12}$ Pasal 8 UUHC.
} 
tindakan Pencipta atau Pemegang Hak untuk melakukan: penerbitan Ciptaan; Penggandaan Ciptaan dalam segala bentuknya; dan penerjemahan Ciptaan. ${ }^{13}$ Setiap Orang yang melaksanakan hak ekonomi sebagaimana dimaksud wajib mendapatkan izin Pencipta atau Pemegang Hak Cipta karena itu setiap Orang yang tanpa izin Pencipta atau Pemegang Hak Cipta dilarang melakukan Penggandaan dan/atau Penggunaan Secara Komersial Ciptaan.

Ketentuan tentang"sold flat" sejalan juga dengan tujuan hukum "kemanfaatan" karena memberikan kegunaan lebih besar kepada pencipta atau pemegang hak cipta untuk memenuhi kebutuhan ekonominya. Selanjutnya berkaitan dengan tujuan hukum ketertiban dan keadilan, adanya pengaturan yang jelas tentang "sold flat" memberikan kepastian hukum terhadap pencipta tentang hak yang dimilikinya setelah berakhir 25 tahun, sehingga ketentuan tersebut merupakan "aturan main" yang tegas dan jelas serta cerminan pedoman "tata tertib" berkaitan dengan bisnis jual lepas Hak Cipta. Dengan demikian, ketentuan tentang "sold flat" memenuhi karakter produk hukum responsif yaitu mencerminkan pemenuhan atas tuntutan-tuntutan baik individu maupun berbagai kelompok sosial di dalam masyarakat sehingga mampu mencerminkan rasa keadilan di dalam masyarakat. ${ }^{14}$ Philippe Nonet dan Selznick, mengemukakan bahwa produk hukum yang berkarakter responsif, proses pembuatannya bersifat partisipasif, yakni mengundang sebanyak-banyaknya partisipasi semua elemen masyarakat, baik dari segi individu ataupun kelompok masyarakat. Kemudian dilihat dari fungsi hukum yang berkarakter responsif tersebut harus bersifat aspiratif yang bersumber dari

\footnotetext{
${ }^{13}$ Selengkapnya lihat Pasal 9 Ayat (1), ibid.

14 Trias Palupi Kurnianingrum, Materi Baru Dalam Undang-Undang Nomor 28 Tahun 2014 Tentang Hak Cipta, jurnal Negara Hukum, Vol. 6, No. 1, Juni 2015 hlm 96, tersedia dalamfile://C:/Users/kiki/Downloads/249-492-1SM\%20(1).pdf [diakses 9/7/2018].
}

keinginan atau kehendak dari masyarakat, produk hukum tersebut bukan kehendak dari penguasa untuk melegitimasikan kekuasaannya, sehingga fungsi hukum dapat menjadi nilai yang telah terkristal dalam masyarakat. ${ }^{15}$

Pengertian "sebelum dan sesudah" berlakunya suatu perundang-undangan dikategorikan sebagai hukum antar waktu yang merupakan bagian dari hukum antar tata hukum. ${ }^{16}$ Hukum antar waktu menunjukkan hukum manakah yang berlaku jika sebuah peristiwa hukum terkait 2 hukum atau lebih yang berlainan yang diakibatkan karena waktu berlakunya yang berbeda dari warga negara dalam suatu Negara. Untuk menentukan suatu hubungan hukum termasuk hukum antar tata hukum (hukum antar waktu) dan hukum mana yang berlaku, maka terdapat 2 (dua) titik pertautan, yaitu titik pertautan primer (pembeda) yang menjelaskan bahwa hubungan hukum tersebut merupakan hukum antar tata hukum karena terdapat 2 (dua) atau lebih hukum yang berlaku dalam suatu hubungan hukum. Sedangkan titik taut sekunder (penentu) adalah untuk menentukan hukum mana yang berlaku dalam hubungan hukum yang terkait dengan 2 (satu) atau hukum yang berlaku.

Ketentuan tentang jual lepas menurut UU No 19 Tahun 2002 tercantum dalam Pasal 3 (2) yang berbunyi :" Hak Cipta dapat beralih atau dialihkan, baik seluruhnya maupun sebagian karena: a. Pewarisan; b. Hibah; c. Wasiat; d. Perjanjian tertulis; atau e. Sebab-sebab lain yang dibenarkan oleh peraturan perundangundangan.” Beralih atau

15 Philippe Nonet dan Philip Selznick, Hukum Responsif, Penerbit Nusa Media, Bandung, 2010, hlm 86-87. lihat juga Trias Palupi Kurnianingrum, ibid.

16 Hukum Antar Tata Hukum (Fakultas Hukum UNPAD menggunakan istilah "Hukum Perselisihan" sebagai mata kuliah wajib bagi mahasiswa Departemen Hukum Perdata). Macam atau bidang Hukum Antar Tata Hukum yaitu : (1). Hukum Antar Golongan; (2). Hukum Antar Adat; (3). Hukum Antar Regio (bagian); (4). Hukum Antar Waktu; (5). Hukum Antar Agama; dan (6). Hukum Perdata Internasional. 
dialihkannya Hak Cipta tidak dapat dilakukan secara lisan, tetapi harus dilakukan secara tertulis baik dengan maupun tanpa akta notariil $^{17}$ karena Hak Cipta termasuk kebendaan bergerak yang tidak berwujud (tidak bertubuh) sehingga tunduk pada Pasal 613 KUHPerdata "Penyerahan piutangpiutang atas nama dan barang-barang lain yang tidak bertubuh, dilakukan dengan jalan membuat akta otentik atau di bawah tangan yang melimpahkan hak-hak atas barangbarang itu kepada orang lain. Penyerahan ini tidak ada akibatnya bagi yang berutang sebelum penyerahan itu diberitahukan kepadanya atau disetujuinya secara tertulis atau diakuinya." Pengaturan jual lepas dalam UU No 19 Tahun 2002 termasuk pengalihan melalui perjanjian tertulis sesuai dengan Buku III KUHPerdata Pasal 1338 (1) tentang asas kebebasan berkontrak. Remy Sjandeini ${ }^{19}$ mengemukakan, bahwa asas kebebasan berkontrak sifatnya universal, artinya berlaku juga pada hukum perjanjian negara-negara lain ${ }^{20}$, dan mempunyai ruang

\footnotetext{
${ }^{17}$ Pasal 3 (1) UU No. 19 Tahun 2002 Tentang Hak Cipta.

${ }^{18}$ Pasal 1338 (1) KUHPerdata: “ setiap perjanjian yang dibuat secara sah berlaku sebagai UU bagi mereka yang membuatnya."

${ }^{19}$ Sutan Remy Sjandeini, Kebebasan Berkontrak dan Perlindungan Hukum yang Seimbang Bagi Para Pihak dalam Perjanjian Kredit Bank di Indonesia, Cetakan Pertama, Institut Bahkir Indonesia, Jakarta, 1993, hlm 47.

20 Negara-negara yang mempunyai sistem hukum Common Law mengenal kebebasan berkontrak dengan istilah Freedom of Contract atau laisseiz faire. Yang dirumuskan oleh Jessel M.R. dalam kasus "Printing and Numerical Registering Co. Vs. Samson ; “...... men of full age understanding shall have the utmost liberty of contracting, and that contracts which are freely and voluntarily entered into shall be held and onforce by the courts..... you are not lightly to interfere with this freedom of contract." Jessel dalam Haridjan Rusli, "Hukum Perjanjian Indonesia dan Common Law”, Pustaka Sinar Harapan, Jakarta, 1993, hlm 39. Lihat juga https://legalbanking.wordpress.com/2012/05/03/asaskebebasan-berkontrak-dalam-standard-kontrakperjanjian-baku-dalam-bidang-bisnis-danperdagangan/[diakses $9 / 7 / 2018$ ].
}

lingkup yang sama seperti juga ruang lingkup asas kebebasan berkontrak dalam hukum perjanjian Indonesia. Namun, kebebasan berkontrak tersebut tidak absolut karena harus memperhatikan ketentuan Pasal 1320 KUHPerdata: "Untuk sahnya suatu perjanjian diperlukan empat syarat: 1. sepakat mereka yang mengikatkan dirinya; 2. kecakapan untuk membuat suatu perikatan; 3. suatu hal tertentu; 4. suatu sebab yang halal.", Pasal 1335 KUHPerdata:" Suatu persetujuan tanpa sebab, atau dibuat berdasarkan suatu sebab yang palsu atau yang terlarang, tidaklah mempunyai kekuatan.", Pasal 1337 KUHPerdata: "Suatu sebab adalah terlarang, apabila dilarang oleh undang-undang, atau apabila berlawanan dengan kesusilaan baik atau ketertiban umum.", Pasal 1338 (3) KUHPerdata:" Suatu perjanjian harus dilaksanakan dengan itikad baik.”, Pasal 1339 KUHPerdata: "Suatu perjanjian tidak hanya mengikat untuk hal-hal yang dengan tegas dinyatakan di dalamnya, tetapi juga untuk segala sesuatu yang menurut sifat perjanjian, diharuskan oleh kepatutan, kebiasaan atau undang-undang.", dan Pasal 1347 KUHPerdata:" suatu sebab adalah terlarang, apabila dilarang oleh undang-undang, atau apabila berlawanan dengan kesusilaan baik atau ketertiban umum."

$$
\text { Berdasarkan Pasal } 1338
$$

KUHPerdata jo Pasal 3 (2) UU No 19 Tahun 2002, perjanjian jual lepas bersifat penyerahan Hak Cipta secara mutlak yaitu hak untuk memperoleh keuntungan ekonomi dari penggunaan atau pemanfaatan hak cipta tersebut tetapi hak moralnya tetap berada pada pencipta, misalnya pencipta tetap berhak namanya dicantumkan dalam ciptaan tersebut meskipun hak ekonominya sudah beralih atau dialihkan kepada pihak lain (penerima atau pembeli Hak Cipta). Perjanjian ini tidak bertentangan dengan pasal-pasal tersebut, karena itu perjanjian jual lepas menurut KUHPerdata mempunyai sesuai dengan syarat sahnya perjanjian sebagaimana diatur dalam Pasal 1320 KUHPerdata mempunyai kekuatan mengikat, sehingga harus ditaati 
oleh kedua belah pihak dan dilaksanakan dengan itikad baik.

Keberadaan hukum antar tata hukum (hukum antar waktu) dalam perjanjian jual lepas atau "sold flat" adalah pada saat dibuatnya perjanjian tersebut berlaku UU No 19 Tahun 2002 Tentang Hak Cipta. Selanjutnya, ketika perjanjian tersebut berlangsung terjadi perubahan UU, yaitu disahkannya UU No 28 Tahun 2014, yang mengatur bahwa Hak Cipta yang telah dijual lepas akan kembali kepada Pencipta setelah 25 tahun. Timbul pertanyaan, UU mana yang berlaku untuk jual lepas "sold flat" tersebut.? Berdasarkan kasus tersebut terdapat titik taut primer (pembeda) karena hubungan hukum tersebut mencerminkan adanya 2 (dua) hukum yang berlaku ( UU No. 19 Tahun 2002 dan UU No. 28 Tahun 2014) yang mengatur tentang jual beli lepas Hak Cipta. Selanjutnya, titik pertautan sekunder (penentu), yaitu titik taut yang menentukan hukum mana yang berlaku apabila dalam hubungan hukum terdapat 2 (dua) atau lebih hukum karena perbedaan waktu.

Hukum antar waktu mengenal beberapa asas hukum yang menjadi pedoman untuk menentukan hukum mana yang berlaku (titik taut sekunder) bila terjadi perubahan perundang-undangan dari yang lama ke yang baru. Beberapa asas itu adalah : ${ }^{21}$

1. Apabila terjadi perubahan peraturan dari yang lama ke yang baru maka yang kemudian berlaku adalah perundang-undangan yang baru itu. Hal ini telah menjadi semacam asas hukum umum yang berlaku diberbagai tempat dan di kenal dengan adagium "lexposterior derogat priori."

2. sesuai dengan prinsip "leges posteriores priores contarias abrogant" maka perundangundangan lama demi hukum

\footnotetext{
${ }^{21}$ https://repository.unikom.ac.id/32535/1/hukum\%20a ntar\%20waktu.doc [diakses 10/7/2018].
}

akan gugur sepanjang isinya bertentangan dengan perundang-undangan yang baru.

3. pembuat hukum atau perundang-undangan dapat menentukan bahwa sebelum perundang-undangan yang baru dinyatakan efektif mulai berlaku, ada masa atau periode waktu tertentu, maka peraturan lama masih dinyatakan masih berlaku. Periode seperti inilah yang dimaksud dengan periode peralihan, dan ketentuan yang menetapkan hal itu disebut Ketentuan Peralihan.

4. bahwa sesuatu perundangundangan tidak mempunyai daya berlaku surut (retroaktif). Maksudnya, sesuatu perundang-undangan setelah disahkan dan diundangkan baru dapat diberlakukan untuk masa kedepan, yang umumnya terhitung mulai tanggal peraturan itu diberlakukan.

Berdasarkan titik taut sekunder pada hukum antar waktu, maka berlaku "lexposterior derogat priori," artinya hukum yang baru (UU No 28 Tahun 2014 mengenyampingkan UU No 19 Tahun 2001). Dengan demikan, apabila jual lepas tersebut dilakukan sebelum tahun 2014 (berlaku UU No 19 Tahun 2002), tetapi kemudian pada saat perjanjian tersebut berjalan terjadi perubahan UU (berlakunya UU No 28 Tahun 2014), maka ketentuan jual lepas Hak Cipta tersebut mengandung klausula menurut UU yaitu setelah waktu tertentu (25 tahun) Hak Cipta yang telah dijual lepas akan kembali kepada penciptanya. Ketentuan jual lepas Hak Cipta dalam UU No 28 Tahun 2014 bersifat memaksa sehingga tidak dapat dikesampingkan oleh para pihak melalui kesepakatan. 
2. Ketentuan Jual Lepas (Sold Flat) berdasarkan UU No. 28 Tahun 2014 dalam Perspektif Pembangunan Ekonomi Nasional di Era Globalisasi.

Menurut Adam Smith, pembangunan ekonomi merupakan proses perpaduan antara pertumbuhan penduduk dan kemajuan teknologi. $^{22} \quad$ Todaro $^{23}$ mengartikan pembangunan sebagai suatu proses multidimensional yang menyangkut perubahan-perubahan besar dalam struktur sosial, sikap masyarakat, kelembagaan nasional maupun percepatan pertumbuhan ekonomi, pengurangan ketidakmerataan dan penghapusan dari kemiskinan mutlak. Menurut Irawan, ${ }^{24}$ pembangunan ekonomi adalah usaha-usaha untuk meningkatkan taraf hidup suatu bangsa yang seringkali diukur dengan tinggi rendahnya pendapatan riil perkapita. Sedangkan, Meier sebagaimana dikutip Adisasmita, 25 mendefinisikan pembangunan ekonomi sebagai proses kenaikan pendapatan riil perkapita dalam suatu jangka waktu yang panjang. Sejalan dengan pendapat tersebut, Sadono Sukirno ${ }^{26}$ mendefinisikan pembangunan ekonomi sebagai suatu proses yang menyebabkan pendapatan perkapita penduduk suatu masyarakat meningkat dalam jangka panjang. Dengan demikian, pembangunan ekonomi nasional pada hakekatnya merupakan perubahan kearah yang lebih baik yaitu peningkatan atau progresivitas pendapatan perkapita yang terjadi pada suatu Negara secara terus menerus dalam rentang waktu yang panjang.

\footnotetext{
${ }^{22}$ Suryana, Ekonomi Pembangunan: Problematika dan Pendekatan, Salemba Empat, Jakarta, 2000, hlm 55.

23 Todaro, Michel, Pembangunan ekonomi didunia ketiga edisi ke tujuh, Balai Aksara, Jakarta, 2010.

24 Irawan dan Suparmoko, Ekonomi Pembangunan, BPFE, Yogyakarta, 2002, hlm 5.

25 Adisasmita. H.R. 2005. Dasar-dasar Ekonomi Wilayah, Graha Ilmu, Jakarta, hlm 205.

${ }^{26}$ Sadono Sukirno, Ekonomi Pembangunan, LPEF-UI Bima Grafika, Jakarta, 1985, hlm 13.
}

Globalisasi berasal dari bahasa inggris (Globalization) yaitu global artinya universal dan "lization" artinya proses. Jadi secara asalusul kata globalisasi yaitu proses pelebaran elemen-elemen baru baik pemikiran, gaya hidup, informasi maupun teknologi dengan tanpa dibatasi batas negara atau mendunia. Globasisasi dapat diartikan sebagai sebuah proses sehingga batas-batas dalam suatu negara menjadi bertambah sempit karena adanya kemudahan dalam berinteraksi antar negara baik perdagangan, gaya hidup, informasi maupun dalam bentuk interaksi yang lain. ${ }^{27}$

Globalisasi perekonomian merupakan salah satu proses ekonomi dan perdagangan, yang mengakibatkan semua negara di dunia menjadi satu kemampuan pasar yang semakin terpadu dengan tidak ada lagi halangan batas wilayah negara. globalisasi perekonomian menghilangkan semua batasan dan kendala pada arus modal, layanan dan barang sehingga batas-batas satu negara menjadi tidak jelas serta adanya keterikatan pada ekonomi nasional dengan perekonomian internasional yang semakin erat. Globalisasi perekonomian pada satu pihak akan membuka kesempatan pada produk yang berasal dari dalam negeri mengarah ke pasar internasional secara kompetitif dan sebaliknya dapat membuka kesempatan masuknya produkproduk global pada pasar domestik. Dengan demikian, globalisasi ekonomi merupakan perpaduan ekonomi nasional menjadi satu sistem ekonomi global yang terpadu dan tersambung menjadi jalinan yang sama-sama memiliki ketergantungan yang bertaraf internasional. $^{28}$

Globalisasi telah meningkatkan interdependensi antar Negara yang salah satunya mempunyai bentuk yakni berlakunya beberapa standard baku internasiona dari beberapa bagian kehidupan, melemahnya ikatan nasional, etnosentrisme, dan primordial

\footnotetext{
27 https://informasiana.com/pengertian-globalisasimenurut-ahli/[diakses 12 /7.2018].

${ }^{28}$ Ibid.
} 
yang berpengaruh pada sektor hukum. Indonesia tidak terlepas dari pengaruh globalisasi hukum. Pada fenomena ini terlihat dari adanya kecenderungan pergantian sektor hukum yang telah dipengaruhi oleh globalisasi yakni diratifikasinya sebagian piranti konvensi hukum internasional yang menjadi hukum nasional indonesia. ${ }^{29}$ Salah satu piranti hukum yang diratifikasi Indonesia adalah Perjanjian TRIPs-WTO berkaitan dengan Hak Cipta.

Hak Cipta adalah hak eksklusif pencipta yang timbul secara otomatis berdasarkan prinsip deklaratif setelah suatu ciptaan diwujudkan dalam bentuk nyata tanpa mengurangi pembatasan sesuai dengan ketentuan peraturan perundang-undangan. ${ }^{30}$ Hal ini berarti untuk mendapatkan Hak Cipta tidak memerlukan pendaftaran, tetapi pendaftaran penting berkaitan dengan pembuktian karena apabila terjadi pelanggaran, pencipta yang mendalilkan bahwa karya tersebut adalah miliknya atau membantah hak orang lain harus membuktikan. $^{31}$ Selanjutnya, idea atau gagasan yang belum terwujud tidak dapat dilindungi oleh rezim hukum Hak Cipta karena yang dilindungi hanya kreasi yang sudah berwujud nyata. Sejalan dengan hal itu, Pasal 28 H mengatakan:" Setiap orang berhak mempunyai hak milik pribadi dan hak milik tersebut tidak boleh diambil alih secara sewenang-wenang oleh siapapun."Oleh karena itu, kebebasan dalam pemilikan Hak Cipta hanya dapat dibatasi sesuai dengan perundang-undangan, misalnya untuk kepentingan tertentu dibidang pendidikan.

Pencipta adalah seorang atau beberapa orang yang secara sendiri-sendiri atau bersama-sama menghasilkan suatu ciptaan yang bersifat khas dan pribadi. ${ }^{32}$ Ciptaan adalah setiap hasil karya cipta di bidang ilmu pengetahuan, seni, dan sastra yang dihasilkan atas inspirasi, kemampuan, pikiran, imajinasi,

\footnotetext{
${ }^{29}$ Ibid.

${ }^{30}$ Pasal 1 Angka 1 UUHC.

${ }^{31}$ Pasal 1865 KUHPerdata.

${ }^{32}$ Pasal 1 Angka 2 UUHC.
}

kecekatan, keterampilan, atau keahlian yang diekspresikan dalam bentuk nyata. ${ }^{33}$ Pemegang Hak Cipta adalah Pencipta sebagai pemilik Hak Cipta, pihak yang menerima hak tersebut secara sah dari Pencipta, atau pihak lain yang menerima lebih lanjut hak dari pihak yang menerima hak tersebut secara sah. ${ }^{34}$ Hak Terkait adalah hak yang berkaitan dengan Hak Cipta yang merupakan hak eksklusif bagi pelaku pertunjukan, producer fonogram, atau lembaga Penyiaran. ${ }^{35}$

Hak Cipta dapat beralih atau dialihkan, baik seluruh maupun sebagian karena: antara lain Perjanjian ${ }^{36}$ tertulis yang dapat berupa Perjanjian untuk berupa perjanjian antara penulis buku dengan penerbit atau pencipta lagu dengan perusahaan rekaman. Ciptaan buku, dan/atau semua hasil karya tulis lainnya, lagu dan/atau musik dengan atau tanpa teks yang dialihkan dalam perjanjian jual putus dan/atau pengalihan tanpa batas waktu, Hak Ciptanya beralih kembali kepada Pencipta pada saat perjanjian tersebut mencapai jangka waktu 25 (dua puluh lima) tahun. Yang dimaksud dengan "hasil karya tulis lainnya" antara lain naskah kumpulan puisi, kamus umum, dan Harian umum surat kabar. Yang dimaksud dengan "jual putus" adalah perjanjian yang mengharuskan Pencipta menyerahkan Ciptaannya melalui pembayaran lunas oleh pihak pembeli sehingga hak ekonomi atas Ciptaan tersebut beralih seluruhnya kepada pembeli tanpa batas waktu, atau dalam praktik dikenal dengan istilah sold flat. ${ }^{37}$

Pengaturan sold flat atau jual lepas memiliki konsekuensi peningkatan ekonomi bagi individu yang bersangkutan karena setelah beralih atau dialihkan kepada pihak lain selama jangka waktu 25 tahun akan kembali kepada pihak yang mengalihkan,

\footnotetext{
${ }^{33}$ Ibid, Pasal 1 Angka 3.

${ }^{34}$ Ibid, Pasal 1 Angka 4.

${ }^{35}$ Ibid, Pasal 1 Angka 5.

${ }^{36}$ Perjanjian adalah suatu perbuatan dengan mana satu pihak atau lebih mengikatkan dirinya terhadap satu orang atau lebih. Lihat Pasal 1313 KUHPerdata.

${ }^{37}$ Penjelasan Umum Pasal 18 UUHC.
} 
sehingga pencipta tersebut dapat menikmati keuntungan ekonomi dari sisa pemanfaatan Hak Cipta tersebut sampai dengan batas akhir perlindungan karya cipta yang bersangkutan, misalnya apabila karya cipta "buku" atau "lagu dan atau musik" dijual lepas, maka setelah 25 tahun kembali lagi kepada penciptanya, sehingga pencipta tersebut masih memiliki masa pemanfaatan hak ekonomi selama 45 tahun, mengingat jangka waktu perlindungan untuk kedua karya cipta tersebut adalah 70 tahun. ${ }^{38}$ Pada tataran makro berimplikasi pada peningkatan ekonomi nasional apalagi pada era globalisasi yaitu ditandai dengan persaingan, maka ketentuan yang melindungi pencipta berkaitan dengan sold flat merupakan upaya mengantisipasi dalam mengharmonisasikan kebijakan legislasi dengan tuntutan global. Dengan demikian, perkembangan hukum antar tata hukum (hukum antar waktu) berkaitan dengan UU Hak Cipta tentang jual lepas (sold flat) berakibat positif terhadap pembangunan ekonomi nasional di Era Globalisasi. Namun, sebagaimana pendapat teori sistem hukum yang dikemukakan oleh Friedman keberhasilan penerapan suatu UU tidak hanya ditentukan oleh faktor substansi hukum (legal substance), tetapi juga penegak hukum (legal structure), dan budaya hukum (legal behavior) masyarakat. Menurut Friedman:'The substance is composed of substantive rules and rules about how institutions should behave. By this is meant the actual rules, norm, and behavioral patterns of people inside the system ...the stress here is on living law, not just rules in law books. "39 Substansi berarti aturan, norma, dan pola perilaku orang-orang di dalam sistem yang sebenarnya ... penekanannya adalah hukum hidup (living law), bukan hanya peraturan dalam perundang-undangan (law in book)."

\footnotetext{
${ }^{38}$ Ibid, Pasal 58.

39 Lawrence W. Friedman, American Law: An Introduction, W.W. Norton and Co, New York, 1984, hlm. 5 .
}

Substansi atau isi hukum sebagai acuan dalam penegakan hukum mempunyai peran penting sebagai pedoman atau pegangan bagi penegak hukum dalam melakukan wewenangnya. Hal ini berarti kelemahan isi hukum akan mengakibatkan penegakan hukum tidak efektif sehingga tujuan yang hendak dicapai tidak terpenuhi. Lebih lanjut diuraikan bahwa

"The structure of a system is
its skeleton or framework;it is
the permanent shape, the
institutional body of the
system, the though rigid nones
that keep the process flowing
within bounds... The structure
of a legal system consists of
elements of this kind: the
number and size of courts;
their jurisdiction that is, what
kind of cases they hear, and
how and why); and modes of
appeal from one court to
another. Structure also means
how the legislature is
organized, how many
members.., what a president
can (legally) do or not do,
what procedures the police
department follows, and so on.
Structure, in a way, is a kind
of cross section of the legal
system? A kind of still
photograph, which freezes the
action." 40 and
Berdasarkan pengertian

Berdasarkan pengertian tersebut secara singkat dapat dikatakan bahwa struktur hukum berkaitan dengan kelembagaan atau penegak hukum termasuk kinerjanya (pelaksanaan hukum). Kemudian, "The legal culture, system their beliefs, values, ideas and expectation. Legal culture refers, then, to those ports of general culture customs, opinions ways of doing and thinking that bend social forces toward from the law and in particular ways. ...in other word, is the

\footnotetext{
${ }^{40}$ Ibid.
} 
climinate of social thought and social force wicch determines how law is used, avoided, or abused." Budaya hukum yang diartikan sistem kepercayaanya, nilai-nilai, idea dan dugaan. Budaya hukum merujuk, kemudian ke kebiasaan budaya umum, cara melakukan pendapat dan berpikir kearah kekuatan sosial dari hukum dan dengan cara tertentu. dengan kata lain, apakah iklim pemikiran sosial dan kekuatan sosial pasti menentukan bagaimana hukum digunakan, dihindari, atau disalahgunakan. ${ }^{41}$

Realitanya, di dalam masyarakat selalu muncul perubahan sosial yaitu perubahan nilai, sikap dan prilaku yang mempengaruhi sistem sosialnya. Perubahan sosial baik yang direncanakan maupun tidak, perubahan sosial yang cepat atau lambat, perubahan sosial yang pengaruhnya besar mapun kecil, dapat mempengaruhi bidangbidang kehidupan lainnya, misalnya hukum. Oleh karena itu, Perubahan sosial dalam upaya membangun masyarakat memerlukan antisipasi perubahan atau penyesuaian hukum karena hukum merupakan refleksi dari solidaritas sosial dalam masyarakat. Dalan hal ini, peranan hukum dalam pembangunan adalah untuk menjamin bahwa pelaksanaan pembangunan dapat berjalan dengan cara yang teratur, tertib dan lancar. Hukum tidak hanya menyesuaikan diri dengan keadaan yang berubah-rubah saja, tetapi justru untuk mengadakan perubahan dan perbaikan keadaan dalam masyarakat. Dengan demikian hukum juga merupakan sebagai suatu alat yang mampu merubah suatu keadaan masyarakat yang kurang baik dan kurang maju serta dapat menciptakan nilai-nilai baru (tool of social engineering) sebagaimana dikemukakan oleh Roscoe Pound. Masyarakat selalu mengalami perubahan-perubahan, perbedaan hanya terdapat pada sifat dan tingkat perubahan itu. Hukum disamping

\footnotetext{
41 Bandingkan dengan

https://dedeandreas.blogspot.co.id/2015/03/teori-

sistem-hukum-lawrence-m-friedman.html, Teori Sistem Hukum Lawrence W. Friedman [diakses 23 /7/2018].
}

mempunyai kepentingan untuk mewujudkan nilai-nilai tertentu di dalam masyarakat terikat pada bahan-bahan yang disediakan oleh masyarakat, sehingga hukum tidak hanya sebagai pengontrol perubahan sosial tetapi hukum juga menerima pengaruh sebagai akibat dari adanya perubahan-perubahan. Lebih lanjut Roscoe Pound membagi kepentingan manusia yang dilindungi hukum menjadi 3 (tiga) macam, yakni: pertama, kepentingan terhadap negara sebagai salah satu badan yuridis. Kedua, kepentingan sebagai negara sebagai penjaga kepentingan sosial. Ketiga, kepentingan terhadap perseorangan terdiri dari pribadi (privacy). ${ }^{42}$

Hukum secara sosiologis adalah penting, dan merupakan suatu lembaga kemasyarakatan (social institusion) yang merupakan himpunan nilai-nilai, kaidahkaidah dan pola-pola perikelakuan yang berkisar pada kebutuhan-kebutuhan pokok masyarakat. ${ }^{43}$ Hukum sebagai suatu lembaga kemasyarakatan, hidup berdampingan dengan lembaga-lembaga kemasyarakatan lainnya dan saling pengaruh mempengaruhi dengan lembaga kemasyarakatan tadi. Hukum dengan perubahan sosial mempunyai hubungan yang sangat erat, karena hukum sebagai sarana pengendalian sosial (social control). Sejalan dengan hal ini, Lawrence M. Friedman berpendapat fungsi hukum itu meliputi pengawasan atau pengendalian sosial (social control), penyelesaian sengketa (dispute settlement), dan rekayasa sosial (social engineering; redistributive; atau innovation). Sedangkan Soerjono Soekanto menyatakan bahwa hukum berfungsi untuk memberikan pedoman kepada warga masyarakat tentang bagaimana harus bertingkah laku atau bersikap dalam menghadapi masalah-masalah dalam masyarakat yang terutama menyangkut kebutuhan-kebutuhan pokok, untuk menjaga keutuhan masyarakat yang bersangkutan, dan menjadi pegangan kepada masyarakat untuk

\footnotetext{
${ }^{42}$ Bernard L. Tanya, dkk, Teori Hukum Strategi Tertib Manusia Lintas Ruang dan Generasi, Genta Publishing, Yogyakarta, 2010, hlm 154.

${ }^{43}$ Soerjono Soekanto
} 
mengadakan pengendalian sosial. Atas dasar uraian itu, maka hukum berperan dalam rangka perubahan sosial sebagai pemberi pedoman dan pengarahan pada masyarakat untuk berprilaku, pengawasan atau pengendalian sosial, dan rekayasa sosial. Dengan kata lain, dari sudut sifatnya dapat dikatakan bahwa pengendalian sosial dapat bersifat preventif maupun represif. Preventif merupakan suatu usaha untuk mencegah terjadinya prilaku menyimpang, sedangkan represi bertujuan untuk mengembalikan keserasian yang terganggu. ${ }^{44}$

Berfungsinya hukum tidak terlepas dari penegakan hukum, yaitu proses dilakukannya upaya untuk tegaknya atau berfungsinya norma-norma hukum secara nyata sebagai dengan pedoman prilaku dalam hubungan-hubungan hukum. ${ }^{45}$ Penegakan hukum berkaitan erat dengan ketaatan bagi pemakai dan pelaksana peraturan perundangundangan, dalam hal ini baik masyarakat maupun penyelenggara negara yaitu penegak hukum. $^{46}$ Fungsi dari penegakan hukum adalah untuk mengaktualisasi aturan-aturan hukum agar sesuai dengan cita-cita hukum sendiri, yakni mewujudkan sikap atau tingkah laku manusia sesuai dengan bingkai yang telah ditetapkan oleh undang-undang atau hukum. Sistem penegakan hukum yang mempunyai nilai-nilai yang baik adalah menyangkut penyerasian antara nilai dengan kaidah serta prilaku nyata manusia. ${ }^{47}$ Secara konsepsional, inti dan arti penegakan hukum terletak pada kegiatan menyerasikan hubungan nilai-nilai yang terjabarkan di dalam kaidah-kaidah yang mantap dan mengejawantah dan sikap tindak sebagai

\footnotetext{
44 Bandingkan dengan http://universityofachehnese.blogspot.co.id/2011/05/h ubungan-hukum-dan-perubahan-sosial.html

${ }^{45}$ Satjipto Raharjo, Masalah Penegakan Hukum Suatu Tinjauan Sosiologis, Sinar Baru. Bandung, 2005, hlm 24.

${ }^{46}$ Shahrul Machmud, Penegakan Hukum Lingkungan Indonesia, Graha ilmu, Yogyakarta, 2012 hlm 132.

${ }^{47}$ Siswanto Sunaryo, Penegakkan Hukum Psikotropika (Dalam Kajian Sosiologi Hukum). PT. Grafindo Persada, Jakarta, 2004, hlm 70-71.
}

rangkaian penjabaran nilai tahap akhir, untuk menciptakan, memelihara dan mempertahankan kedamaian pergaulan hidup $^{48}$

Soerjono Soekanto menjelaskan adalah bahwa efektif atau tidaknya suatu hukum ditentukan oleh 5 (lima) faktor, yaitu : ${ }^{49}$

1. Faktor hukumnya sendiri (undangundang).

2. Faktor penegak hukum, yakni pihakpihak yang membentuk maupun menerapkan hukum.

3. Faktor sarana atau fasilitas yang mendukung penegakan hukum.

4. Faktor masyarakat, yakni lingkungan dimana hukum tersebut berlaku atau diterapkan.

5. Faktor kebudayaan, yakni sebagai hasil karya, cipta dan rasa yang didasarkan pada karsa manusia di dalam pergaulan hidup

UU No 28 Tahun 2014 Tentang Hak Cipta secara substansi telah mengatur secara tegas "sold flat" dan memenuhi syarat yuridis, sosiologis, dan filosofis sebagai upaya meningkatkan perlindungan pencipta atau pemegang hak cipta tetapi harus didukung oleh penegak hukum lainnya langkah-langkah yang perlu dilakukan yaitu: a. Peningkatan kualitas dan kemampuan aparat penegak hukum yang lebih profesional, berintegritas, berkepribadian, dan bermoral tinggi. b. Perlu dilakukan perbaikanperbaikan sistem perekrutan dan promosi aparat penegak hukum, pendidikan dan pelatihan, serta mekanisme pengawasan yang lebih memberikan peran serta yang besar kepada masyarakat terhadap perilaku aparat penegak hukum. c. Mengupayakan peningkatan kesejahteraan aparat penegak

\footnotetext{
48 Soerjono Soekanto, Faktor-faktor yang Mempengaruhi Penegakan Hukum, Rajawali Pers, Jakarta, 2008, hlm 3. Lihat juga http://digilib.unila.ac.id/8907/2/BAB\%20II.pdf [diakses 14/7/2018].

49 Soerjono Soekanto, Faktor-Faktor yang Mempengaruhi Penegakan Hukum, PT. Raja Grafindo Persada, Jakarta, 2008, hlm 8.
} 
hukum yang sesuai dengan pemenuhan kebutuhan hidup. ${ }^{50}$ Dari sisi sarana atau fasilitas pendukung penegakan hukum, perlu dibenahi mengingat faktor ini secara teknis mempengaruhi efektivitas ${ }^{51}$ penegakan hukum. Faktor masyarakat (kesadaran hukum masyarakat)

Perubahan sosial berkaitan dengan perlunya perubahan nilai dan sikap perilaku untuk lebih menghargai pencipta tercermin dari adanya perubahan hukum Hak Cipta dari UU No 19 Tahun 2002 ke UU No 28 Tahun 2014. Upaya untuk lebih menghargai kreasi seorang pencipta didasarkan atas suatu pemikiran bahwa untuk menghasilkan karya cipta diperlukan waktu, biaya, tenaga dan keakhlian tertentu karena itu kepada pencipta perlu diberikan imbalan yang memadai (sesuai teori reward) sehingga pada akhirnya dapat mengembangkan pertumbuhan ekonomi (sesuai teori economic growth stimulus) yang mengakui bahwa perlindungan atas Kekayaan Intelektual merupakan alat dari pembangunan ekonomi, yaitu keseluruhan tujuan dibangunnya suatu sistem perlindungan atas Kekayaan Intelektual yang efektif, ${ }^{52}$ tetapi harus didukung oleh 5 (lima) indikator penegakan sebagaimana dikemukakan oleh Soerjono Soekanto.

\footnotetext{
${ }^{50}$ Bagir Manan, "Penegakan Hukum yg berkeadilan", Varia Peradilan, Jakarta, 2005, No. 245 hlm 7. Lihat juga Sanyoto, "Penegakan Hukum di Indonesia", Jurnal Dinamika Hukum, Fakultas Hukum Universitas Jenderal Soedirman, Vol 8 No 3 September 2008.

${ }^{51}$ Ledy Diana, "Penyakit Sosial dan Efektivitas Hukum di Indonesia", Jurnal Ilmu Hukum, Vol 2 No. 1 Februari 2011, hlm 153. Lihat juga Beta Pandu Yulita, "Penegakan Hukum Pidana Dalam Perlindungan Konsumen Muslim Dari Produk Makanan Yang Tidak Halal Di Kota Pekanbaru", JOM Fakultas Hukum Volume III Nomor 2, Oktober 2016.

52 Robert M Sherwood, Intellectual Property and Economic Development: Westview Special Studies in Science, Technology and Public Policy, Westview Press Inc, San Fransisco, 1990, hlm 41. Lihat juga Ranti Fauza Mayana, Perlindungan Desain Industri di Indonesia dalam Era Perdagangan Bebas, Grasindo, Jakarta, 2004, hlm. 46.
}

\section{PENUTUP}

Simpulan :

(1). Titik pertautan sekunder keberlakuan UU No. 28 Tahun 2014 terhadap UU No. 19 Tahun 2002 berdasarkan "lexposterior derogat priori" (hukum yang baru mengenyampingkan hukum yang lama).

(2). Ketentuan tentang "Jual Putus (sold flat)" dapat menjadi sarana Pembangunan Ekonomi Nasional di Era Globalisasi apabila didukung dengan penegak hukum yang konsisten, sarana fasilitas yang memadai, kesadaran hukum masyarakat dan budaya hukum yang kondusif.

Saran :

(1). Perlu disahkan Peraturan Pelaksanaan yang diamanatkan melalui pasal-pasal dalam UU No. 28 Tahun 2014, sehingga kepastian hukum berkaitan dengan keberlakukan UU tersebut terjamin.

(2). Perlu sosialisasi tentang kaidah atau norma yang baru setelah keberlakuan Undang-Undang Nomor 28 Tahun 2014, terutama berkaitan dengan "Jual Putus (sold flat)," sehingga pencipta atau pemegang hak cipta memahami penggunaan hak ekonomi yang dimilikinya.

\section{Buku}

\section{DAFTAR PUSTAKA}

Adisasmita, H.R. Dasar-dasar Ekonomi Wilayah. Jakarta : Graha Ilmu, 2005.

Asshiddiqie, Jimly. Hukum Acara Pengujian Undang-Undang. Sekretariat Jenderal dan Kepaniteraan Mahkamah Konstitusi RI : Jakarta Pusat, 2005.

Bernard L. Tanya, dkk. Teori Hukum Strategi Tertib Manusia Lintas Ruang dan Generasi. Yogyakarta : Genta Publishing, 2010. 
Diana, Ledy. "Penyakit Sosial dan Efektivitas Hukum di Indonesia". Jurnal Ilmu Hukum, Vol 2 No. 1 Februari 2011.

Friedman, Lawrence W. American Law: An Introduction. New York : W.W. Norton and Co, 1984.

Haridjan, Rusli. Hukum Perjanjian Indonesia dan Common Law. Jakarta : Pustaka Sinar Harapan, 1993.

Irawan dan Suparmoko, Ekonomi Pembangunan. Yogyakarta : BPFE, 2002.

Kurnianingrum, Trias Palupi. Materi Baru Dalam Undang-Undang Nomor 28 Tahun 2014 Tentang Hak Cipta. Jurnal Negara Hukum, Vol. 6, No. 1, Juni 2015.

Mayana, Ranti Fauza. Perlindungan Desain Industri di Indonesia dalam Era Perdagangan Bebas. Jakarta : Grasindo, 2004.

Machmud, Shahrul. Penegakan Hukum Lingkungan Indonesia. Yogyakarta : Graha Ilmu, 2012.

Nonet, Philippe dan Philip Selznick, Hukum Responsif. Bandung : Penerbit Nusa Media, 2010.

Purbacaraka, Purnadi dan Soerjono Soekanto, Perihal Kaidah Hukum. Cet. Keempat. Bandung : Alumni, 1986.

Raharjo, Satjipto. Masalah Penegakan Hukum Suatu Tinjauan Sosiologis. Bandung : Sinar Baru, 2005.

Sanyoto. "Penegakan Hukum di Indonesia". Jurnal Dinamika Hukum, Fakultas Hukum Universitas Jenderal Soedirman, Vol 8 No 3 September 2008.

Sherwood, Robert M, Intellectual Property and Economic Development: Westview Special Studies in Science, Technology and Public Policy, Westview Press Inc, San Fransisco, 1990.

Sjandeini, Sutan Remy. Kebebasan Berkontrak dan Perlindungan Hukum yang Seimbang Bagi Para Pihak dalam Perjanjian Kredit Bank di Indonesia, Cetakan Pertama. Jakarta : Institut Bankir Indonesia, 1993.

Soekanto, Soerjono. Faktor-faktor yang Mempengaruhi Penegakan Hukum. Jakarta : Rajawali Pers, 2008.

Soeprapto, Maria Farida Indrati. Ilmu Perundangundangan, Dasar-dasar dan Pembentukannya. Yogyakarta : Kanisius, 1988.
Sukirno, Sadono. Ekonomi Pembangunan. Jakarta : LPEF-UI Bima Grafika, 1985.

Sunaryo, Siswanto. Penegakkan Hukum Psikotropika (Dalam Kajian Sosiologi Hukum). Jakarta : PT. Grafindo Persada, 2004.

Suryana. Ekonomi Pembangunan : Problematika dan Pendekatan. Jakarta : Salemba Empat, 2000.

Todaro, Michel, Pembangunan ekonomi didunia ketiga edisi ke tujuh. Jakarta : Balai Aksara, 2010.

Yulita, Beta Pandu. "Penegakan Hukum Pidana Dalam Perlindungan Konsumen Muslim Dari Produk Makanan Yang Tidak Halal Di Kota Pekanbaru”. JOM Fakultas Hukum Volume III Nomor 2, Oktober 2016.

\section{Peraturan Perundang-Undangan}

Kitab Undang-Undang Hukum Perdata

Republik Indonesia, UU No. 19 Tahun 2002 Tentang Hak Cipta.

Republik Indonesia, UU No 28 Tahun 2014 Tentang Hak Cipta.

Republik Indonesia, Keputusan Presiden Nomor 74 Tahun 2004.

Konvensi Wina 1969

\section{Dokumen/Literatur}

World Intellectual Property Organization Performances and Phonograms Treaty (Perjanjian Karya-Karya Pertunjukan dan Karya-Karya Fonogram WIPO)

Bagir Manan, "Penegakan Hukum yg berkeadilan", Varia Peradilan, Jakarta, 2005, No. 245.

Website/Internet

file:///C:/Users/kiki/Downloads/249-492-1SM\%20(1).pdf [diakses 9/7/2018].

http://digilib.unila.ac.id/8907/2/BAB\%20II.pdf [diakses 14/7/2018].

https://informasiana.com/pengertian-globalisasimenurut-ahli/[diakses 12/7.2018].

https://repository.unikom.ac.id/32535/1/hukum\%2 Oantar\%20waktu.doc [diakses 10/7/2018].

http://universityofachehnese.blogspot.co.id/2011/ 05/hubungan-hukum-dan-perubahansosial.html

http://www.landasanteori.com/2015/09/hak-ciptasejarah-Perkembangan. html. [diakses 5/7/2018]. 